Article

\title{
Inequality Perceptions, Preferences Conducive to Redistribution, and the Conditioning Role of Social Position
}

\author{
Matthias Fatke \\ Department of Political Science, Ludwig-Maximilians-University, München 80539, Germany; \\ matthias.fatke@gsi.lmu.de
}

Received: 31 August 2018; Accepted: 11 October 2018; Published: 16 October 2018

\begin{abstract}
Inequality poses one of the biggest challenges of our time. It is not self-correcting in the sense that citizens demand more redistributive measures in light of rising inequality, which recent studies suggest may be due to the fact that citizens' perceptions of inequality diverge from objective levels. Moreover, it is not the latter, but the former, which are related to preferences conducive to redistribution. However, the nascent literature on inequality perceptions has, so far, not accounted for the role of subjective position in society. The paper advances the argument that the relationship between inequality perceptions and preferences towards redistribution is conditional on the subjective position of respondents. To that end, I analyze comprehensive survey data on inequality perceptions from the social inequality module of the International Social Survey Programme (1992, 1999, and 2009). Results show that inequality perceptions are associated with preferences conducive to redistribution particularly among those perceived to be at the top of the social ladder. Gaining a better understanding of inequality perceptions contributes to comprehending the absence self-correcting inequality.
\end{abstract}

Keywords: inequality; perceptions; redistribution; social rank; system justification

\section{Introduction}

Rising inequality poses one of the biggest challenges of our time. Skewed distributions of resources within societies have been made responsible for a range of political and social issues. Yet, rising levels of inequality have not increased public demand for redistributive measures [1], as the political economy literature would suggest [2]. As Dahl [3] (p. 95) pointed out, however: "Between a condition of objective inequality and the response of a disadvantaged person lie the perceptions, evaluations, expectations-in short, the psyche of the individual." So, it should not come as too much of a surprise that the nascent literature on inequality perceptions casts doubt on citizens' knowledge about the level of inequality in their respective country [3-9].

In fact, subjective perceptions of inequality seem to be related to preferences, which are conducive to redistribution [10-17]. I believe this perception based argumentation needs to be qualified as it fails to acknowledge the role of the subjective position within society [18-20]. Therefore, this paper advances the argument that the relationship between inequality perceptions and preferences conducive to redistribution is conditional on the subjective position of respondents. In particular, I juxtapose two hypotheses. The first assumes economic self-interest and expects an amplifying interaction, the second assumes system justification and expects a weakening interaction.

To test this conditional argument, I make use of measures of inequality perceptions in the social inequality module of the International Social Survey Programme (ISSP), which has been administered in 1992, 1999, and 2009. Merging these individual survey data with Solt's Standardized World Income Inequality Database (SWIID) [21], I first corroborate findings that perceptions of inequality 
are unrelated to income inequality and also vary substantially in one and the same society. Second, I find that subjective position in society significantly moderates the relationship between inequality perceptions and preferences for redistribution.

By gaining a better understanding of inequality perceptions, the paper contributes to comprehending the link between the contextual characteristic of inequality and individual preferences. The findings further emphasize the need to take individual (mis)perceptions and psychological processes explicitly into account. Otherwise, any theoretical argument about political consequences of macro-level phenomena, based on the assumption of correct perceptions, may prove to be oversimplified and underspecified. On the practical side, the findings might offer implications for policy-making and the political process in general.

\section{Theoretical Background}

For any contextual characteristic to explain social phenomena there must be an explicit, empirically testable argument via the "units at a level below that of the system" [22] (p. 2). Yet, many arguments about inequality merely assume that the, by definition, macro-level characteristic directly connects to the micro-level of individual preferences. The Meltzer-Richards-hypothesis, for instance, implies greater support for redistribution in the face of inequality as the median voter benefits from redistribution [2]. While this hypothesis has been contested empirically, more recent analyses indicate that, particularly within countries, greater inequality is indeed linked to stronger demand for redistribution among median voters $[23,24]$. But in order to develop greater demand for redistribution, it is arguably necessary that citizens perceive greater inequality. In most analyses of preferences of the median voter, this remains a potentially oversimplifying assumption [12] (p. 30). According to Dahl's path from the existence of objective inequality to the individual response, consequences of inequality involving human behavior depend on "perceptions, evaluations, expectations-in short, the psyche of the individual" [25] (p. 95).

This distinction becomes particularly significant as individuals are found to widely misperceive objective inequality [3-9]. In the absence of accurate knowledge of inequality, individuals resort to heuristics, which are prone to bias [26]. Kelley and Evans propose that individuals blend what they see through their materialist filter with generalizations from reference groups [27]. When people apply a representativeness heuristic, erroneously assuming their social environment was representative of the society, they commit to extension neglect [28]. Inferring the level of inequality from the immediate social environment is biased not only because individuals sort themselves into homogenous groups in terms of wealth and status $[29,30]$. Even without self-selection, the mean of any sub-sample of the highly skewed income distribution will be a biased estimator for the society as a whole. In sum, diverging perceptions from objective inequality might result from individuals' failure to deal with the concept of variance [8], to evaluate the degree of inequality in relation to other countries or previous levels, and to assess their society as a whole beyond their immediate surroundings [10].

In light of these challenges, we need to reconsider arguments about political preferences conducive to redistribution. With perceptions being independent from objective inequality, there is little reason to expect citizens in objectively more unequal societies to form attitudes that would result in redistributive efforts. However, if citizens perceive the social context to be unequal, they are likely to suffer from relative deprivation and stress [31]. To amend this situation, they are more susceptible to demand equality. Thus, evidence in favor of the Meltzer-Richards-hypothesis can be found when it is based on perceived rather than on objective inequality [11-15,17]. Consequently, I expect perceptions of more unequal societies to be associated with preferring more income equality, demanding government intervention to reduce differences in incomes, losing faith in meritocracy, and supporting more progressive taxation. All these attitudes are not only vital to eventually achieve redistribution democratically, but they also imply increasing degrees of responsibility. Whereas the former two merely express a general position and put responsibility on the government, believing in meritocracy and, particularly, supporting progressive taxation entail a stronger, personal component implying 
willingness to sacrifice their achievements in order to address inequality. This becomes important as the following argumentation draws on the individual situation of citizens.

Going beyond previous analyses, I advance the conditional argument that relationships between perceptions and attitudes conducive to redistribution depend on the perceived societal position of a given individual. Social status itself is, of course, an important determinant of political behavior [20]. Again, subjective perception of status is only loosely correlated with objective measures [32,33], with a strong tendency to place oneself in the middle of the social hierarchy [30], and it is the former that shapes political preferences $[18,34]$. Since greater inequality implies greater differences in social status, it stands to reason that perceived inequality matters differently for citizens on who perceive themselves on different rungs of the social ladder. Jazmin, Kristjen, and Stephanie [19] (p. 259) note in this regard, "little research has investigated the psychological mechanisms that may result from the interaction between inequality and SES to explain their joint impact on political attitudes and behavior".

Theoretically, two opposite interactions are conceivable. On the one hand, perceiving greater inequality could be associated even more strongly with preferences conducive to redistribution for those who feel to be at the bottom of society, because they would benefit most in financial terms. Equally, if those at the top perceive society to be unequal, supporting redistribution would be against their own economic interest. This leads to the hypothesis that the association between inequality perceptions and preferences conducive to redistribution is positive and stronger, the lower the perceived societal position. Evidently, this reasoning is based on a rational-choice conception of redistributive preferences. Similar to the reasoning behind the Meltzer-Richards-hypothesis, it eventually implies a self-correcting mechanism. If enough citizens perceive society to be unequal and themselves to be at the lower rungs of the social ladder, they hold preferences, which demand more redistribution. Given the self-interest maximizing nature, the hypothesis presumably applies to those preferences in particular that imply more self-responsibility (such as progressive taxation and meritocracy) as opposed to a general position that does not imply one's immediate contribution (such as government intervention and preferring equality).

On the other hand, research on psychological processes behind inequality and social status point to more intricate mechanisms than selfish, economic self-interest. For instance, it shows that inequality does not make the "have-nots" more likely to be conscious about their class belonging (only the "haves" less likely) [35]. An explanation for this can be provided by system justification theory [36,37], according to which individuals adopt motivated cognition, lending support and justification for the social arrangement, even if they are disadvantaged by it. Dissonance theory furthermore argues that the disadvantaged, rationalizing the status quo, should commit to the very causes of their circumstances. It provides support for this counter-intuitive phenomenon: Individuals who perceive larger income differences in their society are more likely to praise them as legitimate [38]. The hypothesis by [39] (p. 123), that "[s]ystem justification levels will be higher in societies in which social and economic inequality is more extreme rather than less extreme" would thus suggest an alternative interaction. This leads to the hypothesis that those who feel to be at the bottom of society experience a greater need to reduce cognitive dissonance, resulting in a weaker association between perceiving high inequality and expressing preferences conducive to redistribution. I moreover hypothesize that this applies rather to those preferences that imply little contribution (such as government intervention and preferring equality) and less to those that imply effort and self-responsibility (such as progressive taxation and meritocracy).

\section{Data and Research Design}

Attempts to measure perceptions of inequality in a comparative manner are rather rare. One valuable exception can be found in the social inequality module of the International Social Survey Programme (ISSP), which has been administered in several countries across the world in 1992, 1999, and 2009 (The module in the 1987 wave does not include the item used to measure inequality perceptions). Respondents are asked to indicate which out of five diagrams best describes the situation in their country. Based on the presentation in [16] (p. 3), Figure 1 reproduces the question. The five diagrams 
from which respondents could choose are sorted from the most unequal society (Type A) to the most equal (Type E). Compared to other attempts, this way is the "most appropriate method to measure how individuals perceive income inequality" [40]. After all, it does not require citizens to have an understanding of how variance of a distribution translates into a number, but provides a straightforward assessment encompassing a comprehensive conceptualization of inequality.

This subjective measure of perception is contrasted with objective measures of income inequality from the Standardized World Income Inequality Database (SWIID) by [21]. The SWIID does not only comprise Gini estimates for many country-years by incorporating several data sources, but also allows taking measurement uncertainty into account by multiply imputing values. Figure 1 shows how perceptions of inequality are distributed across all country-years in the sample ranked according to their Gini coefficients of income inequality after taxes and transfers (Gini net) expressed as a percentage shown in far right column. Evidently, respondents in all country-years express varying perceptions about how unequal their society is regardless of the objective level of inequality. That is true both between, as well as within countries. For instance, respondents in Slovenia, Slovakia or the Czech Republic perceive inequality strikingly similar to respondents in the U. S. or Israel although the former are among the most equal countries, while the latter are among the most unequal. And although inequality has risen considerably in many countries, such as in Latvia or Bulgaria, between 1999 and 2009, perceptions of inequality have remained astonishingly the same. In Australia people seem to perceive society to be more equal although income inequality has slightly risen.

Further analyses (not shown) scrutinize the independence of subjective perceptions from objective inequality by regressing various operationalizations of inequality on the perception variable: Change of Gini net from the last year, mean of Gini net over time, change of Gini net from its mean over time, and income inequality before taxes and transfers (Gini market). None of these inequality indicators is significantly associated with perceptions of inequality. Neither do respondents systematically over-nor underestimate inequality (cf. [3,5,9]), underscoring that their perceptions are simply independent from any objective measure of inequality.

In the following section, I test the hypotheses using multilevel modelling, due to the hierarchic data structure. These models allow for varying-slopes for inequality perceptions and include three levels with individual observations nested in 69 country-years, which are, in turn, nested in 27 countries. Furthermore, we include several control variables that have shown to be important for redistributive preferences and have been held constant in previous analyses (e.g., $[12,14,14,17,23])$. On the individual level, I am careful to include only controls that precede the explanatory variable [41] (p. 188), and hold perceived position in society, age, age squared, sex, and level of education constant. On the contextual level, the sample comprises a rather diverse set of countries. Since idiosyncrasies in terms of economic and political development potentially bias inequality perceptions between countries, I control for a country's income inequality after taxes and transfers, its level of democracy, its human capital (average years of schooling and rate of return to education), and gross domestic product (GDP) per capita. Measures are taken from Solt's SWIID [21], Polity IV, and Penn World Table [42], respectively.

Regarding preferences relevant for redistribution, I consider the following dependent variables: Preferring income equality, demanding government intervention, believing in meritocracy, and supporting progressive taxation. To test the argument about a conditional relationship, a multiplicative interaction term between inequality perception and perceived societal position is included. Appendix A lists the items as they were asked in the ISSP surveys for all dependent and constitutive variables.

In order to deal with missing values, I apply multiple imputation. The final data consists of ten data sets each representing a (randomly drawn) multiple imputation of the SWIID values joined with imputed ISSP values for 88,167 respondents. Accordingly, I compute each model for each of the ten data sets and report the average of estimates. Since the imputation model produces continuous values [43] (p. 850), I estimate linear models. This also facilitates model convergence and interpretation. Still, results are the same when estimating ordered logit models or (binary) logit models with various splits instead. 


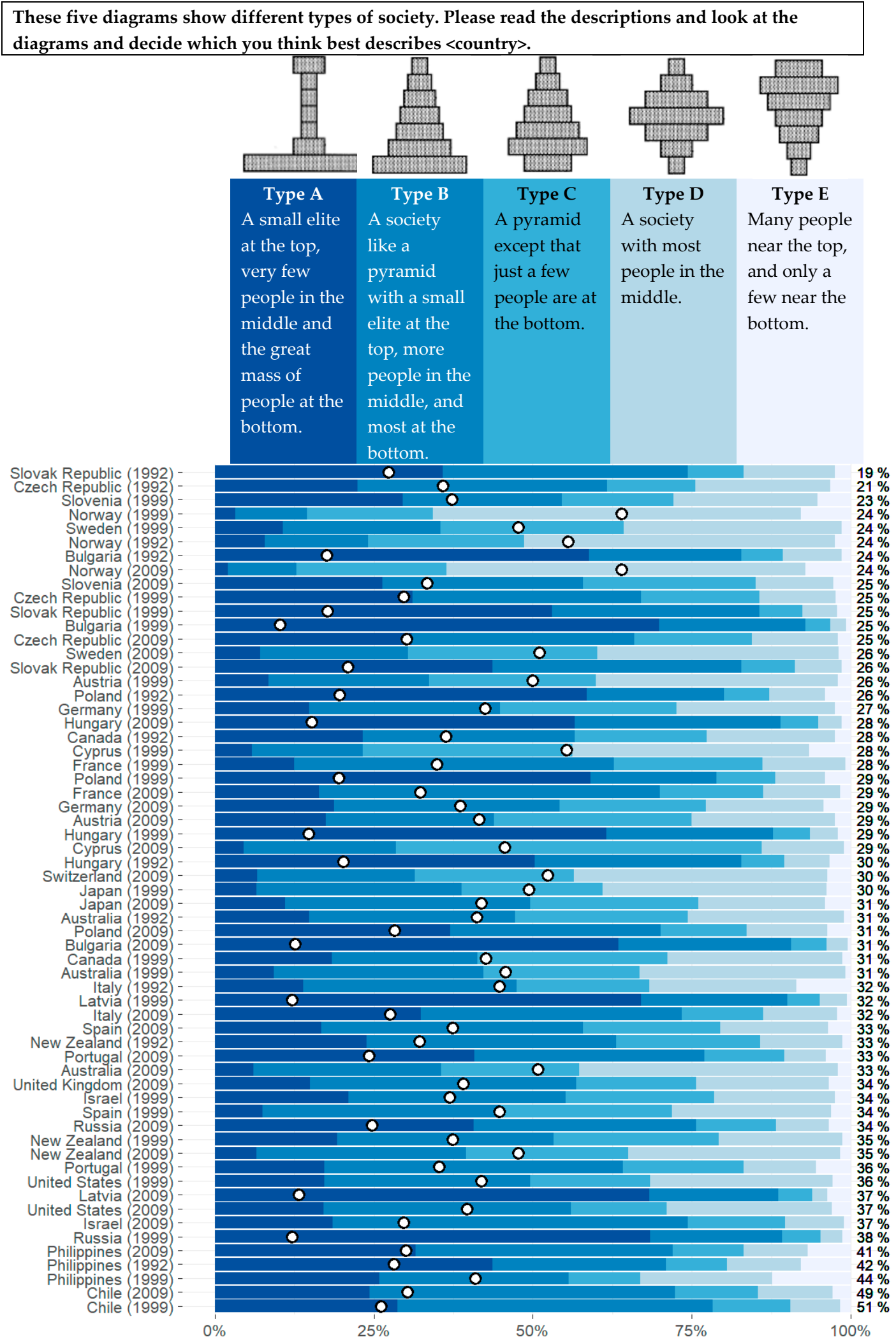

Figure 1. Distributions of income perceptions across countries. Black circles represent means per country-year. Country-years sorted by Gini net according to [21] expressed as a percentage shown in far right column. Note: Figure 1 is inspired by the presentation in [16], Data and question based on Q14 in ISSP 1992, 1999, 2009. 


\section{Results}

Figure 2 presents results of multilevel regression models for the four preferences relevant for redistribution, including an interaction term of inequality perceptions and social status. Regression tables and models without interaction terms can be found in Appendix B (Table A1) and Appendix C (Figure A1), respectively. Concerning coefficients of the constitutive terms, inequality perceptions are significantly related to preferences. People who perceive their society to be more unequal also think income differences are too large, it's the government's responsibility to reduce income differences, hard work is not important to get ahead in life, and the rich should pay a larger share of their income in taxes. Due to the interaction term, these interpretations apply when the standardized variable for subjective social status is zero (i.e., at the mean value of subjective social status). Models without the interaction term (reported in Appendix C) show the same relationships. Interestingly, objective inequality is not associated with preferences in the same way. Coefficients of the standardized Gini coefficient after taxes and transfers are smaller and the standard errors so large that they include zero in three out of four models.

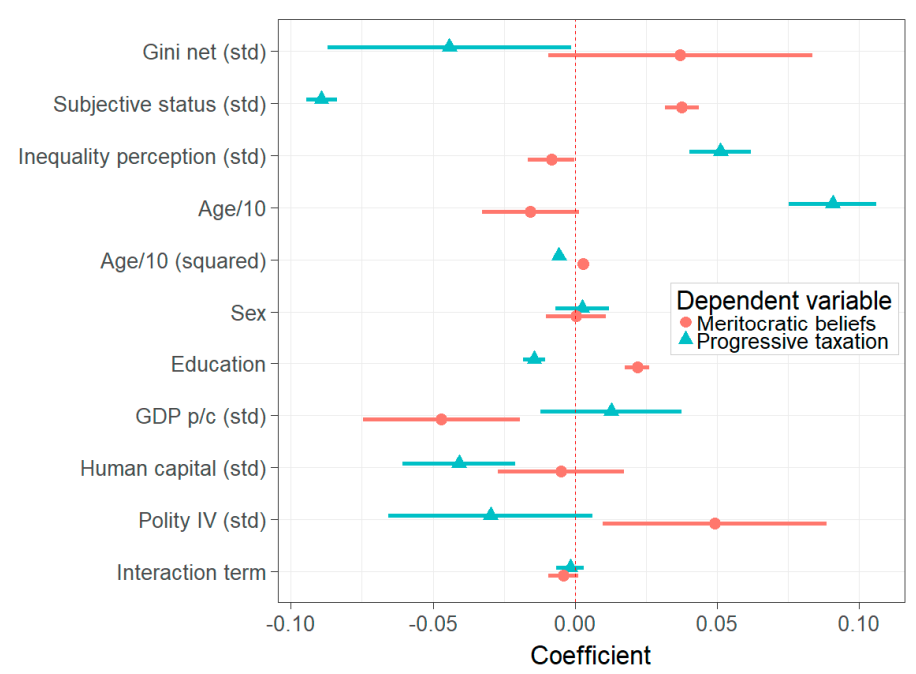

(a) Models for meritocratic beliefs and progressive taxation

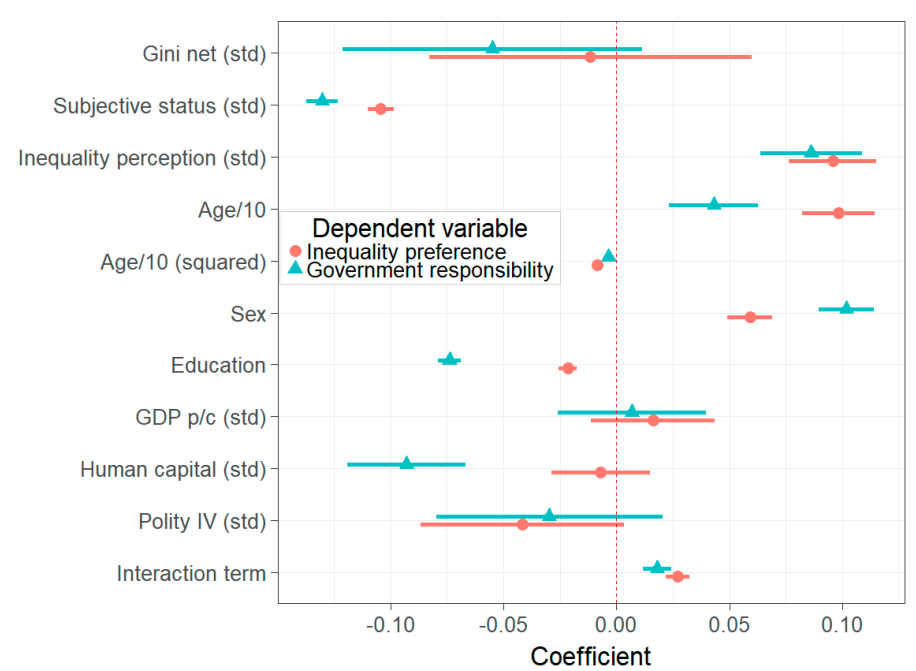

(b) Models for inequality preference and government responsibility

Figure 2. Fixed effect coefficients from varying-intercept, varying-slope models of meritocratic beliefs and progressive taxation (a), and inequality preference and government responsibility (b). 
The finding that perceptions of inequality, and not objective levels, predict preferences relevant for redistribution is much in line with recent research [10-17]. Emphasizing the necessity to take psychological processes on the individual level into account, it can serve as explanation why inequality is not self-correcting as the Meltzer-Richards-hypothesis suggests. But in how far are these relationships, as previously argued, conditional on perceived social status? Coefficients of the interaction terms in Figure 2 are somewhat ambiguous. In two of the four models, coefficients do not reach statistical significance. For preferences implying self-responsibility and effort, interactions indicate that the relationships do not differ according to social status. For inequality preference and government responsibility, on the other hand, the coefficients indicate a significant moderation. To evaluate the conditionality for these dependent variables further, Figure 3 illustrates marginal coefficients conditional on subjective social status (on the $x$-axis). The range of the $x$-axis is limited to the range of the standardized variable in the ISSP data before imputation.

Rather steep slopes in the left panels (and to some degree in the upper right panel) of Figure 3 confirm that relationships between inequality perceptions and those political preferences depend on where in society a respondent ranks herself. In contrast, more progressive taxation is preferred by citizens of all ranks if they perceive society to be unequal. The results also provide an answer to the direction of the interaction. It is, notably, not the case that a subjectively deprived situation amplifies the association. Rather, it applies to those who rank themselves at the top as they favor more income equality and government intervention, and also believe less in meritocracy. For those at the bottom, in contrast, these associations are substantially weaker. While the $x$-axis in Figure 3 shows only the range of the original, un-imputed variable, the associations become even statistically insignificant when estimated for extremely low imputed values of subjective status (i.e., below -2.2025). That is striking because they would have the most to gain from redistributive efforts. Therefore, the finding might make more sense as evidence of system justification and dissonance theory [36,37]. Individuals who feel disadvantaged and perceive society as unequal rationalize the situation and lend support to the social arrangement in so far as they do not demand change in form of redistribution [39] (p. 123). I return to discussing further implications of this finding in the concluding section.

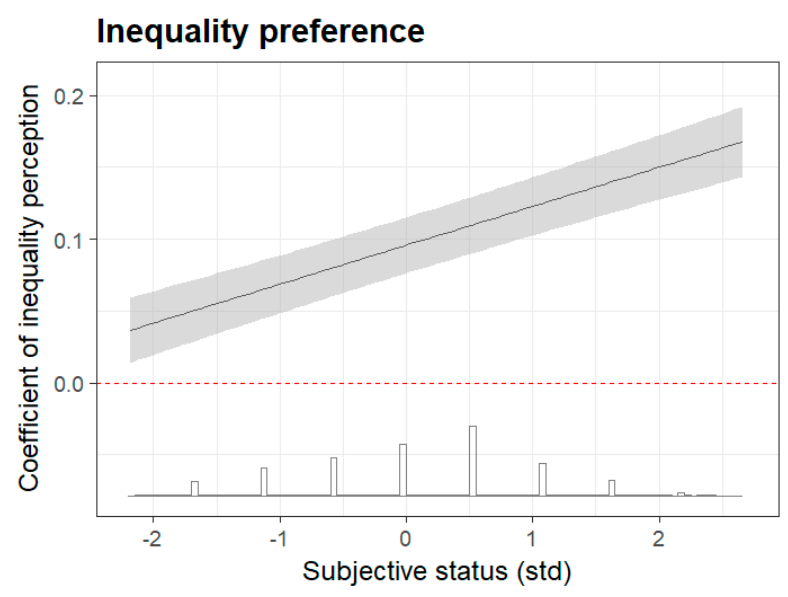

(a) Model for inequality preference

Figure 3. Cont. 


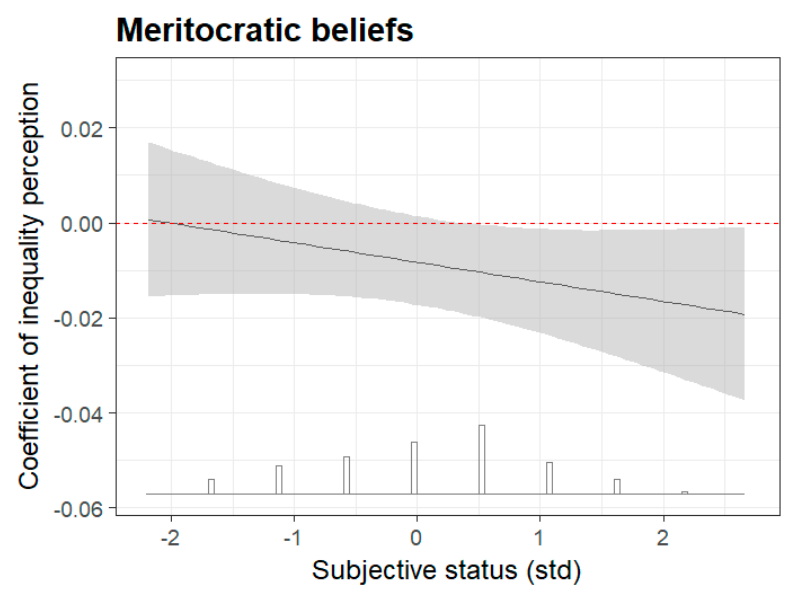

(b) Model for Meritocratic beliefs

Government responsibility

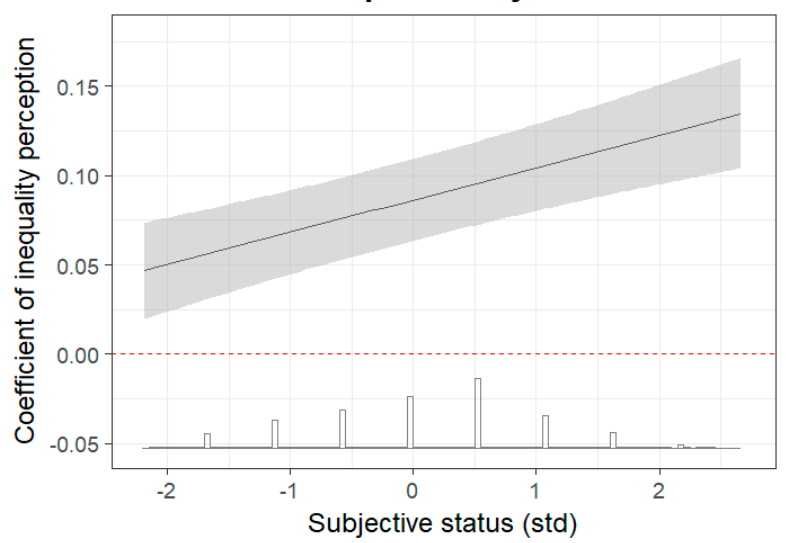

(c) Model for Government responsibility

Progressive taxation

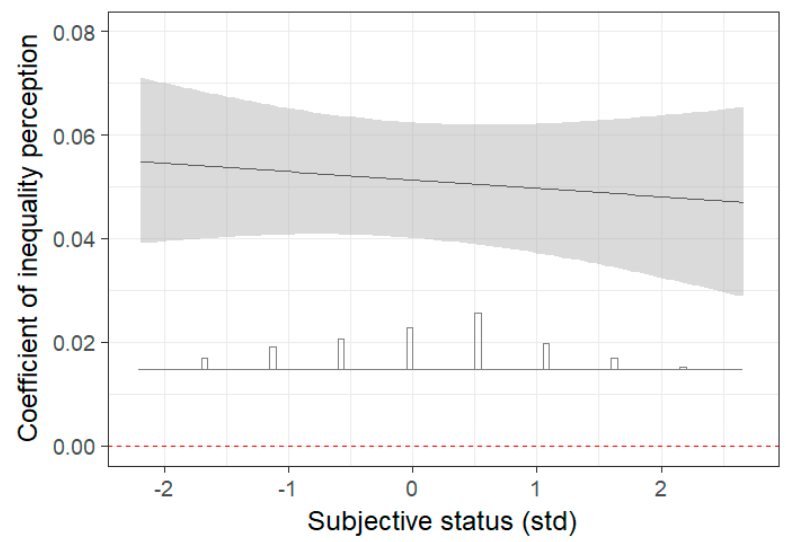

(d) Model for Progressive taxation

Figure 3. Marginal coefficients of inequality perception conditional on perceived social status for inequality preference (a), meritocratic beliefs (b), government responsibility (c), and progressive taxation $(\mathbf{d})$.

\section{Conclusions}

In 2004, the APSA Task Force on Inequality and American Democracy [44] (p. 661), recognizing the perils of growing inequalities, called for more research into "changing economic inequality and changes in political behavior". But in light of recent findings univocally demonstrating the mismatch between individual perceptions of inequality and actual, objective levels [3-17], it seems warranted 
to further scrutinize the relationships between inequality perceptions and preferences conducive to redistribution.

The results corroborate the fact that people perceive inequality differently from the actual level. Explicitly examining the link between a macro-level phenomenon and individual behavior has important implications with particular relevance in the political realm where many theories naturally relate societal conditions with political behavior. For instance, it cites Marx's thesis that workers faced with inequalities should "unite and overthrow the rich" [45] (p. 125). Marx's prediction not coming true despite rising inequality might be due to the fact that individuals do not perceive inequality as it is. Hence, it should come as anything but a surprise that inequality does not have the supposed consequences for politics. The analysis of survey data from the ISSP adds to the literature by showing that the relationship between inequality perceptions and preferences concerning redistribution particularly apply to those who believe to be at the top of society, and not to those who would actually benefit from more redistribution. Notably, this applies to general positions towards redistribution, but not to support for more progressive taxation, which implies that those who perceive to be at the top would actually have to make an effort in paying more taxes.

Perhaps most importantly, it sheds further light on why inequality is not only not decreasing, but in fact increasing in many countries. In addition to flaws and shortcomings of democratic systems not being able to fully translate political preferences of the majority into policies [46], citizens apparently do not hold preferences that would be beneficial to them in the first place. Instead, the formation of preferences happens more intricately achieving psychosocial aims like system justification and dissonance reduction. As a concrete consequence, public opinion on tax cuts is often ill-informed and independent from relevant values and material interests [47]. This logic does not only apply to inequality. In many domains, researchers have recently pointed out diverging trends between objective measures and subjective perception: Crime rates [48], violence [49], democratic governance [50], happiness [51], and other social domains, such as health, employment, security, and social ranking [52]. For the functioning of democracy, this divide is crucial. Voters mandate politicians to change objective measures according to their preferences. Politicians, however, have an incentive to rather influence perceptions of voters-because this is what gets them elected.

These implications suggest at least five avenues for further research. First, the finding that inequality perceptions seem to be independent of objective levels begs the question on what basis inequality perceptions are formed in the first place. Further scrutiny is needed to compare and explain differences in inequality perceptions. Possible starting points could be socialization and personal experiences or party attachment. Second, it seems fruitful to test perceptions of inequality in other instances as well, since inequality is usually made responsible for a whole range of social issues, including well-being, tolerance, social trust, and happiness. Second, as inequality is only one (albeit a crucial) condition of society, it would make sense to apply the argument to other instances where perceptions probably deviate from objective levels. If appropriate measures are available, it can be tested, for instance, whether perceptions of crime rates and violence instead of official numbers are associated with individual behavior. Third, this study, relying on correlations of individual responses, is unable to assess the causality between inequality perceptions and political behavior. While my focus is rather, among which respondents there is an association, it would be interesting to gather experimental data. For example, experiments could answer which treatments affect perception of inequality and how large the causal effect of treated perceptions on political behavior is. Finally, the question remains if and how perceptions of inequality result in policy measures targeting, and eventually reducing, inequality. Are exaggerated perceptions in the public necessary for to the introduction of policy instruments adopted to counter inequality? I hope this study can serve as inspiration and point of departure for further research into these questions.

Funding: This research received no external funding.

Conflicts of Interest: The author declares no conflict of interest. 


\section{Appendix A}

ISSP items used for operationalization of constitutive and dependent variables from modules Social Inequality and Citizenship

\section{Perceived Social Position}

In our society there are groups which tend to be towards the top and groups which tend to be towards the bottom. Below is a scale that runs from top to bottom. Where would you put yourself now on this scale?

\section{Inequality Perception}

These five diagrams show different types of society. Please read the descriptions and look at the diagrams and decide which you think best describes your country.

\section{Inequality Preference}

Differences in income in your country are too large.

\section{Government Responsibility}

It is the responsibility of the government to reduce the differences in income between people with high incomes and those with low incomes.

\section{Meritocratic Beliefs}

Please tick one box for each of these to show how important you think it is for getting ahead in life: How important is hard work?

\section{Progressive Taxation}

Do you think people with high incomes should pay a larger share of their income in taxes than those with low incomes, the same share, or a smaller share?

\section{Appendix B}

Table A1. Regression tables from varying-intercept, varying-slope models of political preferences.

\begin{tabular}{|c|c|c|c|c|}
\hline & Inequality Preference & Government Responsibility & Meritocratic Beliefs & Progressive Taxation \\
\hline \multirow[t]{2}{*}{ Gini net (std) } & -0.01 & -0.05 & 0.04 & -0.04 \\
\hline & $(0.04)$ & $(0.03)$ & $(0.02)$ & $(0.02)$ \\
\hline \multirow[t]{2}{*}{ Subjective status (std) } & -0.10 & -0.13 & 0.04 & -0.09 \\
\hline & $(0.00)$ & $(0.00)$ & $(0.00)$ & $(0.00)$ \\
\hline \multirow[t]{2}{*}{ Inequality perception (std) } & 0.10 & 0.09 & -0.01 & 0.05 \\
\hline & $(0.01)$ & $(0.01)$ & $(0.00)$ & $(0.01)$ \\
\hline \multirow{2}{*}{ Age/10 } & 0.10 & 0.04 & -0.02 & 0.09 \\
\hline & $(0.01)$ & $(0.01)$ & $(0.01)$ & $(0.01)$ \\
\hline \multirow{2}{*}{ Age/10 (squared) } & -0.01 & -0.00 & 0.00 & -0.01 \\
\hline & $(0.00)$ & $(0.00)$ & $(0.00)$ & $(0.00)$ \\
\hline \multirow[t]{2}{*}{ Sex } & 0.06 & 0.10 & 0.00 & 0.00 \\
\hline & $(0.01)$ & $(0.01)$ & $(0.01)$ & $(0.00)$ \\
\hline \multirow[t]{2}{*}{ Education } & -0.02 & -0.07 & 0.02 & -0.01 \\
\hline & $(0.00)$ & $(0.00)$ & $(0.00)$ & $(0.00)$ \\
\hline \multirow{2}{*}{ GDP p/c (std) } & 0.02 & 0.01 & -0.05 & 0.01 \\
\hline & $(0.01)$ & $(0.02)$ & $(0.01)$ & $(0.01)$ \\
\hline \multirow[t]{2}{*}{ Human capital (std) } & -0.01 & -0.09 & -0.00 & -0.04 \\
\hline & $(0.01)$ & $(0.01)$ & $(0.01)$ & $(0.01)$ \\
\hline \multirow[t]{2}{*}{ Polity IV (std) } & -0.04 & -0.03 & 0.05 & -0.03 \\
\hline & $(0.02)$ & $(0.03)$ & $(0.02)$ & $(0.02)$ \\
\hline \multirow[t]{2}{*}{ Interaction term } & 0.03 & 0.02 & -0.00 & -0.00 \\
\hline & $(0.00)$ & $(0.00)$ & $(0.00)$ & $(0.00)$ \\
\hline Intercept & 3.96 & 3.83 & 3.95 & 3.81 \\
\hline Country-year intercept & 0.02 & 0.02 & 0.02 & 0.01 \\
\hline Country-year slope & 0.00 & 0.00 & 0.00 & 0.00 \\
\hline Country intercept & 0.05 & 0.04 & 0.01 & 0.01 \\
\hline Country slope & 0.00 & 0.83 & 0.00 & 0.00 \\
\hline
\end{tabular}


Table A1. Cont.

\begin{tabular}{ccccc}
\hline & Inequality Preference & Government Responsibility & Meritocratic Beliefs & Progressive Taxation \\
\hline AIC & 199,403 & 234,585 & 210,536 & 190,121 \\
BIC & 199,581 & 234,763 & 210,714 & 190,299 \\
\hline
\end{tabular}

Note: Data from ISSP waves 1992, 1999, 2009. Estimates are based on 88167 individual observations in 69 country-years in 27 countries. Coefficients and standard errors (in parentheses), and model parameters are averaged over 10 multiply imputed data sets. Standardized variables are marked with (std). Varying-slopes are estimated for inequality perceptions (std).

\section{Appendix C}

Coefficient plots from varying-intercept, varying-slope models of political preferences without interaction terms.

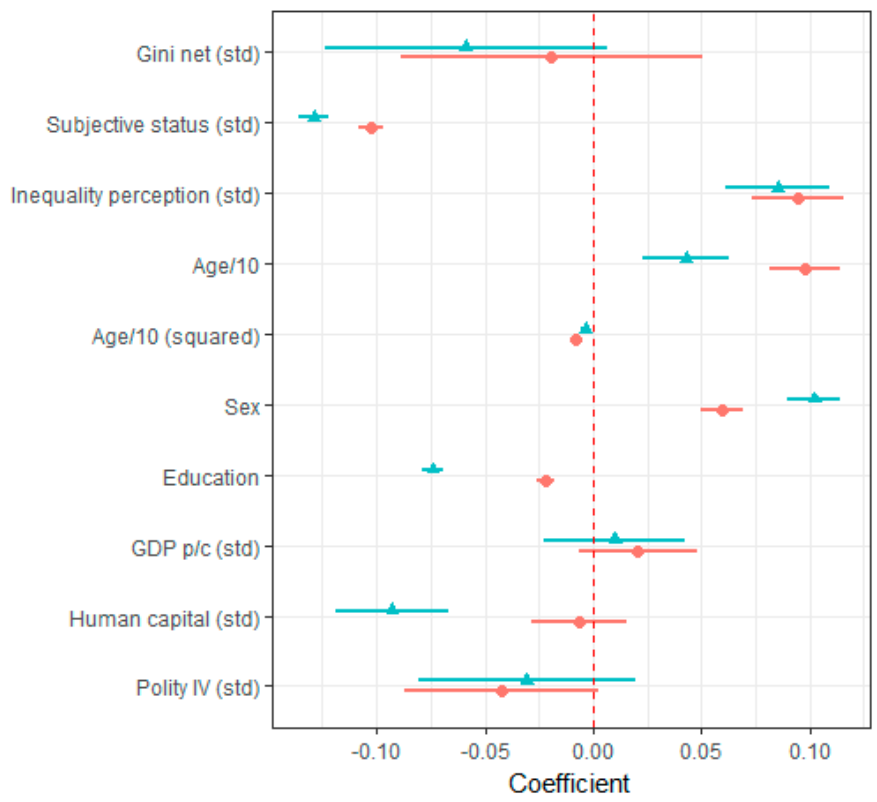

Dependent variable

- Inequality preference

- Government responsibility

(a)

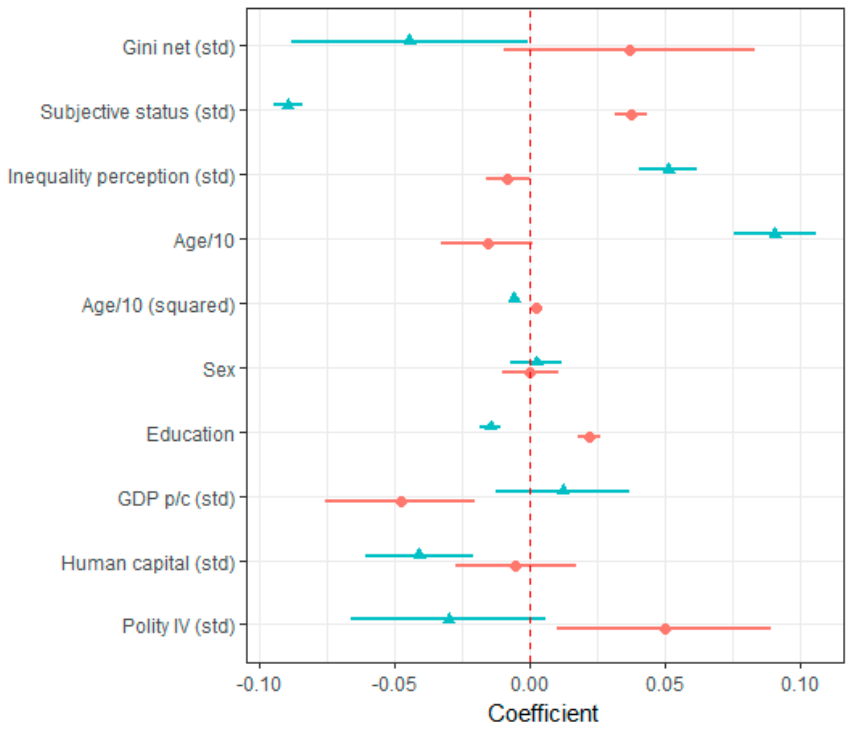

Dependent variable

- Meritocratic beliefs

- Progressive taxation

(b)

Figure A1. Fixed effect coefficients from varying-intercept, varying-slope models of inequality preference and government responsibility (a), and meritocratic beliefs and progressive taxation (b). 


\section{References}

1. Starmans, C.; Sheskin, M.; Bloom, P. Why people prefer unequal societies. Nat. Hum. Behav. $2017,1$. [CrossRef]

2. Meltzer, A.H.; Richard, S.F. A Rational Theory of the Size of Government. J. Political Econ. 1981, 89, 914-927. [CrossRef]

3. Chambers, J.R.; Swan, L.K.; Heesacker, M. Better off than we know: Distorted perceptions of incomes and income inequality in America. Psychol. Sci. 2014, 25, 613-618. [CrossRef] [PubMed]

4. What Do Germans Think and Know about Income Inequality? A Survey Experiment. Available online: https://academic.oup.com/ser/advance-article/doi/10.1093/ser/mwx036/4558624 (accessed on 15 August 2018).

5. Eriksson, K.; Simpson, B. What do Americans know about inequality? It depends on how you ask them. Judgm. Decis. Mak. 2012, 7, 741-745.

6. Fernández-Albertos, J.; Kuo, A. Income Perception, Information, and Progressive Taxation: Evidence from a Survey Experiment. Political Sci. Res. Methods 2018, 6, 83-110. [CrossRef]

7. Hauser, O.P.; Norton, M.I. (Mis)perceptions of inequality. Curr. Opin. Psychol. 2017, 18, 21-25. [CrossRef] [PubMed]

8. Kim, E.; Pedersen, R.T.; Mutz, D.C. What Do Americans Talk about When They Talk about Income Inequality? 2016. Available online: https:/ / ssrn.com/abstract=2805330 (accessed on 15 August 2018).

9. Norton, M.I.; Ariely, D. Building a better America-One wealth quintile at a time. Perspect. Psychol. Sci. 2011, 6, 9-12. [CrossRef] [PubMed]

10. Cruces, G.; Perez-Truglia, R.; Tetaz, M. Biased perceptions of income distribution and preferences for redistribution: Evidence from a survey experiment. J. Public Econ. 2013, 98, 100-112. [CrossRef]

11. Engelhardt, C.; Wagener, A. Biased Perceptions of Income Inequality and Redistribution; CESIFO Working Paper 4838; CESIFO: Dresden, Germany, 2014.

12. Gimpelson, V.; Treisman, D. Misperceiving Inequality. Econ. Political 2018, 30, 27-54. [CrossRef]

13. Kuhn, A. In the eye of the beholder: Subjective inequality measures and individuals' assessment of market justice. Eur. J. Political Econ. 2011, 27, 625-641. [CrossRef]

14. Kuhn, A. The Subversive Nature of Inequality: Subjective Inequality Perceptions and Attitudes to Social Inequality. CESifo Working Paper Series No. 6023. 2016. Available online: https://ssrn.com/abstract= 2829308 (accessed on 15 August 2018).

15. Kuziemko, I.; Norton, M.I.; Saez, E.; Stantcheva, S. How elastic are preferences for redistribution? Evidence from randomized survey experiments. Am. Econ. Rev. 2015, 105, 1478-1508. [CrossRef]

16. Niehues, J. Subjective Perceptions of Inequality and Redistributive Preferences: An International Comparison; IW-Trends Discussion Paper 2/2014; IW NEWS: Köln, Germany, 2014.

17. Yanai, Y. Perceived Inequality and Support for Redistribution. 2017. Available online: https://ssrn.com/ abstract=2937637 (accessed on 15 August 2018).

18. Brown-Iannuzzi, J.L.; Lundberg, K.B.; Kay, A.C.; Payne, B.K. Subjective status shapes political preferences. Psychol. Sci. 2015, 26, 15-26. [CrossRef] [PubMed]

19. Brown-Iannuzzi, J.L.; Lundberg, K.B.; McKee, S. Political Action in the Age of High-Economic Inequality: A Multilevel Approach. Soc. Issues Policy Rev. 2017, 11, 232-273. [CrossRef]

20. Payne, K. The Broken Ladder: How Inequality Affects the Way We Think, Live, and Die; Penguin: London, UK, 2017.

21. Solt, F. The Standardized World Income Inequality Database. Soc. Sci. Q. 2016, 97, 1267-1281. [CrossRef]

22. Coleman, J.S. Foundations of Social Theory; Harvard University Press: Cambridge, MA, USA, 1990.

23. Finseraas, H. Income inequality and demand for redistribution: A multilevel analysis of European public opinion. Scand. Political Stud. 2009, 32, 94-119. [CrossRef]

24. Schmidt-Catran, A.W. Economic inequality and public demand for redistribution: Combining cross-sectional and longitudinal evidence. Soc. Econ. Rev. 2014, 14, 119-140. [CrossRef]

25. Dahl, R.A. Polyarchy: Participation and Opposition; Yale University Press: New Haven, CT, USA, 1973. 
26. Kahneman, D.; Tversky, A. Subjective probability: A judgment of representativeness. Cognit. Psychol. 1972, 3, 430-451. [CrossRef]

27. Kelley, J.; Evans, M.D. Class and class conflict in six western nations. Am. Sociol. Rev. 1995, 60, 157-178. [CrossRef]

28. Tversky, A.; Kahneman, D. Judgment under Uncertainty: Heuristics and Biases. Science 1974, 185, $1124-1131$. [CrossRef] [PubMed]

29. Dawtry, R.J.; Sutton, R.M.; Sibley, C.G. Why wealthier people think people are wealthier, and why it matters from social sampling to attitudes to redistribution. Psychol. Sci. 2015, 26, 1389-1400. [CrossRef] [PubMed]

30. Evans, M.D.; Kelley, J. Subjective social location: Data from 21 nations. Int. J. Public Opin. Res. 2004, 16, 3-38. [CrossRef]

31. Wilkinson, R.G.; Pickett, K.E. Income inequality and social dysfunction. Annu. Rev. Sociol. 2009, 35, 493-511. [CrossRef]

32. Brown-Iannuzzi, J.L.; Payne, B.K.; Rini, C.; DuHamel, K.N.; Redd, W.H. Objective and subjective socioeconomic status and health symptoms in patients following hematopoietic stem cell transplantation. Psycho-Oncology 2014, 23, 740-748. [CrossRef] [PubMed]

33. Singh-Manoux, A.; Marmot, M.G.; Adler, N.E. Does subjective social status predict health and change in health status better than objective status? Psychosom. Med. 2005, 67, 855-861. [CrossRef] [PubMed]

34. Krauss, M.W. The Inequality of Politics: Social Class Rank and Political Participation. IRLE Working Paper No. 120-15. 2015. Available online: http://irle.berkeley.edu/workingpapers/120-15.pdf (accessed on 15 August 2018).

35. Solt, F.; Hu, Y.; Hudson, K.; Song, J.; Yu, D.E. Economic inequality and class consciousness. J. Political 2017, 79, 1079-1083. [CrossRef]

36. Jost, J.T.; Banaji, M.R. The role of stereotyping in system-justification and the production of false consciousness. Br. J. Soc. Psychol. 1994, 33, 1-27. [CrossRef]

37. Jost, J.T.; Pelham, B.W.; Sheldon, O.; Ni Sullivan, B. Social inequality and the reduction of ideological dissonance on behalf of the system: Evidence of enhanced system justification among the disadvantaged. Eur. J. Soc. Psychol. 2003, 33, 13-36. [CrossRef]

38. Trump, K.S. Income inequality influences perceptions of legitimate income differences. Br. J. Political Sci. 2017, 48, 929-952. [CrossRef]

39. Jost, J.; Hunyady, O. The psychology of system justification and the palliative function of ideology. Eur. Rev. Soc. Psychol. 2003, 13, 111-153. [CrossRef]

40. Schalembier, B. Measuring perceived income inequality: An evaluation of different methods. Presented at the Statistical Conference SIS 2015, Treviso, Italy, 9-11 September 2015.

41. Gelman, A.; Hill, J. Data Analysis Using Regression and Multilevel Hierarchical Models; Cambridge University Press: Cambridge, UK, 2007.

42. Feenstra, R.C.; Inklaar, R.; Timmer, M.P. The Next Generation of the Penn World Table. Am. Econ. Rev. 2015, 105, 3150-3182. Available online: www.ggdc.net/pwt (accessed on 30 June 2018). [CrossRef]

43. Gelman, A.; King, G.; Liu, C. Not asked and not answered: Multiple imputation for multiple surveys. J. Am. Stat. Assoc. 1998, 93, 846-857. [CrossRef]

44. Schlozman, K.; Lehman, B.I.; Page, S.; Verba, M.F. Inequalities of Political Voice; Task Force on Inequality and American Democracy, American Political Science Association: Washington, DC, USA, 2004.

45. Norton, M.I. All ranks are local: Why humans are both (painfully) aware and (surprisingly) unaware of their lot in life. Psychol. Inq. 2013, 24, 124-125. [CrossRef]

46. Bartels, L.M. Unequal Democracy: The Political Economy of the New Gilded Age; Princeton University Press: Princeton, NJ, USA, 2016.

47. Bartels, L.M. Homer gets a tax cut: Inequality and public policy in the American mind. Perspect. Political 2005, 3, 15-31. [CrossRef]

48. Ardanaz, M.; Corbacho, A.; Ibarraran, P.; Ruiz-Vega, M. Mind the Gap: Bridging Perception and Reality with Crime Information; IADB Working Paper; IADB: Washington, DC, USA, 2013.

49. Pinker, S. The Better Angels of Our Nature: The Decline of Violence in History and Its Causes; Penguin: London, UK, 2011. 
50. Achen, C.H.; Bartels, L.M. Democracy for Realists: Why Elections Do Not Produce Responsive Government; Princeton University Press: Princeton, NJ, USA, 2016.

51. Boyce, C.J.; Brown, G.D.; Moore, S.C. Money and happiness: Rank of income, not income, affects life satisfaction. Psychol. Sci. 2010, 21, 471-475. [CrossRef] [PubMed]

52. Lora, E.A. The Distance between Perception and Reality in the Social Domains of Life (August 2013); IDB Working Paper No. IDB-WP-423; IDB: Washington, DC, USA, 2013. 